\title{
北海道礼文島における表土利用エを用いた植生基材注入 エの植生モニタリング
}

\section{菖蒲哲也 1,2$)$ - 岸野和哉 1,3$)$ - 塚田篤德 *1,3) - 山田 守 4)}

1）日本特殊緑化協会

2）株式会社アヤメ緑化工業

3）株式会社きら昭建

4) SPTEC • YAMADA

摘要 : 北海道礼文島内の斜面緑化工事において埋土種子を含む表 土を用いた植生基材注入工（表土利用工）の植生モニタリング結 果を報告する。調査地は, 斜面勾配が急であること, 寒冷地で植 物の生育が遅いこと, 国立公園内であり生物多様性に配慮し, 外 来種を用いた早期緑化が出来ないことなどから, 植物生育基盤の 耐侵食性が課題であった。この課題に対して, 植生基材注入工を 用いて長期間の生育基盤の安定を図っている。植生モニタリング 結果では，植被率は緩慢ではあるが増加傾向にある。出現種は, 施工後 2 年 7 カ月経過している斜面では 32 種を確認し在来草本が 優占していた。課題として, 外来種の割合が多いなどの課題が見 られた。

キーワード : 表土利用工, 寒冷地, 急勾配, 国立公園, 生物多様 性保全

\section{1. はじめに}

近年, 生物多様性保全に配慮した緑化工法として, 表土利 用工, 自然侵入促進工, 地域性種苗利用工が注目されている。 それぞれ, 自然回復緑化対策として有効な緑化工法であるが, 課題も多く残されている。例えば，表土利用工では表土の採 取や保管場所の確保が困難な場合が多い, 自然侵入促進工で は緑化完成までの生育基盤の耐侵食性や完成する植物群落が 予想できないなど，地域性種苗利用工では緑化工事までに必 要な種苗を用意することが困難な場合が多い, 種苗が高価な ごである 2)。これらの課題解決には，具体的な事例検証を積 み重ねることが重要と考える。

本報告の調査地は，日本最北端の島である礼文島の西海岸 に面した海蝕崖地形の斜面で，風当たりが強い場所にある。ま た，国立公園内に位置しており一般の斜面緑化で利用されて いる外来種の使用は制限されている。斜面の勾配は最大で 68 度（1:0.4）と急勾配である。このような立地条件で可能な生 物多様性保全に配慮した緑化工法として埋土種子を含む表土
を配合した植生基材注入工を実施した。

本報告では，施工段階から施工後 2 年 7 力までの初期生 育に関する植生モニタリング結果について報告する。

\section{2. 調査地および施工方法の概要}

\section{1 調査地の概要}

調查地は，北海道礼文郡礼文町船泊村に位置し，礼文島の 西海岸に面している。調査地のすぐ近くに美しい海と海蝕崖 地形の奇岩や入江などで観光客が集まる澄海岬がある。気候 は，覀寒帯気候に属し寒冷である。気象庁による過去の気象 データでは，調查地の最寄りの観測所「船泊」はデータ不足 で平年值は公表されていないが, 1978～2003 年の 26 年間の 平均值は, 年降水量 $966 \mathrm{~mm}$, 日平均気温は $6.6{ }^{\circ} \mathrm{C}$ ある。 また同期間の最大風速は $25 \mathrm{~m} / \mathrm{s}$ （1984 年）で，風向は北北 西〜西北西に卓越する傾向が見られる。したがって, 礼文島 の西海岸に位置する調査地は, 礼文島内においても風当たり が強い場所と言える。調査地周辺の景観を写真-1 に示す。

また，礼文島全体に寒地・高山植物群落が発達し，各所に お花畑も見られレブンアツモリソウ（Cypripedium macranthos Sw. var. flavum Mandl.) に代表される数多く の希少種や固有種が生育していることが知られている ${ }^{1 ） 。 な ~}$

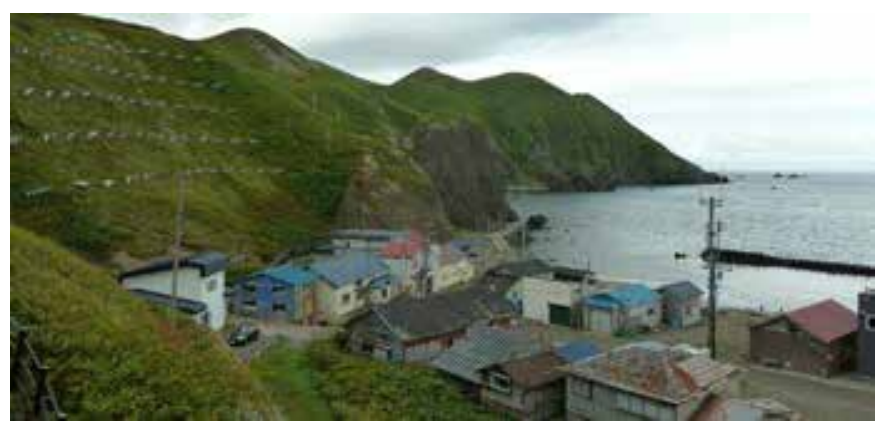

写真-1 調査地周辺の景観

* 連絡先著者：E-mail : a.tsuka@jsra-web.com $\bar{\mp} 003-0001$ 北海道札幌市白石区東札幌 1 条 2 丁目 2 番 16 号 


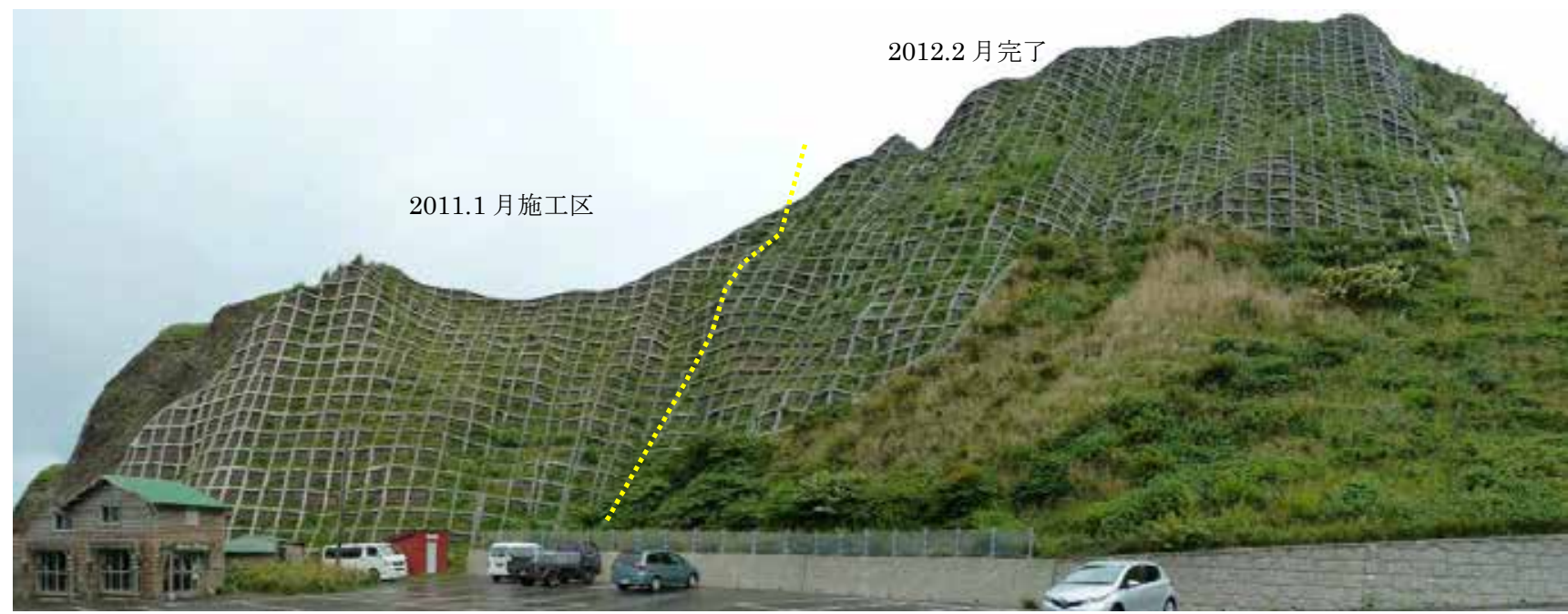

写真-2 調查斜面の全景（2013 年 8 月 23 日撮影）

お，調查地は，利尻礼文サロベツ国立公園内に位置しており， 利尻礼文サロベッ国立公園管理計画書 1) では, 許可・届出 等取扱い方針の緑化関連の事項として「島外からの植物導入 を避け，現地に適した緑化工法として，施行区域周辺の自然 植生からの種子や表土（埋土種子）を使用した吹付緑化工法 を採用するように努める」としている。

\section{2 緑化工法の選定}

調査地の斜面条件および斜面対策工の概要を表- 1 に示す。 斜面は崩壊跡地で斜面保護工として吹付法枠工が実施されて おり，緑化対策は法枠内である。斜面の勾配は，均一では無 く最も急な箇所は 68 度 (1:0.4) 程度である（写真-2）。

緑化工法の選定に当たっては, 急勾配であること, 風が強 い場所であることから生育基盤の侵食が危惧された。また， 寒冷地で植物の生育期間が短いこと, 緑化植物は外来種を用 いないで島内に自生している植物や埋土種子を用いる必要が あることから，早期全面緑化は期待できないため緑化完成ま でに時間がかかることが予想された。

これらのことを考慮し, 生育基盤の長期間安定確保が可能 な工法として, 植生基材注入工（表土配合）を選定した。植 生基材注入工は，連続したポリエチレン製の袋を斜面に敷設 しアンカーピンで固定した後, 植生基材を袋内に注入する工 法である。吹付緑化工法と異なり冬期間や強風の中でも施工 が可能である点で, 当地の施工条件に適した工法と判断した。

\section{3 表土の選定}

表土は，緑化施工前に撒きだし試験により埋土種子の確認 を行った。撒きだし試験は， 3 力所の採取候補地より表土サ ンプルを採取し，プランターに厚さ $15 \mathrm{~cm}$ で土壤改良材（バ 一ミキュライト）を敷き詰め，その表層に表土を $3 \mathrm{~cm}$ 撒き だした。撒きだし後は適宜灌水し，発芽した出現種の同定お よび成立本数を測定した。表土のサンプリングは 2009 年 12 月に, 撒きだしは 2010 年 1 月に実施した。撒きだし 6 カ月 後の 2010 年 8 月まで観察を行った。

表-1 斜面条件および斜面対策工の概要

\begin{tabular}{|c|c|c|}
\hline & 項目 & 内容 \\
\hline \multirow{4}{*}{$\begin{array}{l}\text { 斜面の } \\
\text { 条件 }\end{array}$} & 勾配 & 最大 68 度（1:0.4） \\
\hline & 方位 & 南西向き \\
\hline & 標高 & 0 約 $20 \mathrm{~m}$ \\
\hline & 地質 & 軟岩 II （山中式土壌硬度 $35 \mathrm{~mm}$ 以上） \\
\hline \multirow[t]{6}{*}{ 対策工 } & 施工時期 & 2011.1 月施工区（2010 年度） \\
\hline & & 2012.2 月施工区（2011 年度） \\
\hline & 斜面保護工 & 吹付法枠工 \\
\hline & 植生工 & 植生基材注入工 （表土配合） $\mathrm{t}=10 \mathrm{~cm}$ \\
\hline & 植生工の施工面 & 2011.1 月施工区 $1,198 \mathrm{~m}^{2}$, \\
\hline & 積（法枠工内） & 2012.2 月施工区 $1,788 \mathrm{~m}^{2}$ \\
\hline
\end{tabular}

表-2＼cjkstart表土の撒きだし試駼結果

\begin{tabular}{|c|c|c|c|c|}
\hline 項目 & 区分 & $\begin{array}{c}\text { 表土 } \\
\text { サンプル A }\end{array}$ & $\begin{array}{c}\text { 表土 } \\
\text { サンプル B }\end{array}$ & $\begin{array}{c}\text { 表土 } \\
\text { サンプル C }\end{array}$ \\
\hline \multirow{4}{*}{$\begin{array}{c}\text { 出現種数 } \\
\text { (種) }\end{array}$} & 木本 & 14 & 15 & 14 \\
\hline & 草本 & 2 & 3 & 1 \\
\hline & 不明 & 0 & 2 & 4 \\
\hline & 合計 & 16 & 20 & 19 \\
\hline 成立本数 & $\left.m^{2}\right)$ & 582 & 296 & 116 \\
\hline
\end{tabular}

撒きだし試験の結果を表-2 に示す。なお，撒きだし試験の 発芽個体は幼少で，科名までは同定できたが，種名まで同定 出来ないものが多かった。3 カ所の表土サンプルの出現種数 の合計は 16〜20 種であった。成立本数 116 582 本 $/ \mathrm{m}^{2}$ とば らつきが見られた。また, ハイウシノケグサ (Festuca rubra var. genuina Hack.) など外来種も見られ，特に表土サンプ ル Aに多かった。なお，外来種をまったく含まない表土を採 取することは困難であること, 新たな外来種を島内に持ち込 むものではないことから，これらの表土は緑化材料として利 用可能と判断し, 比較的外来種が少なかった表土サンプル B 
の箇所が表土採取箇所として最も望ましいと判断した。

\section{4 施工状況}

緑化施工は, 2011 年 1 月施工区と 2012 年 2 月施工区の 2 工区ある（表-1）。いずれも冬季施工で強風の中での施工で あった。植生基材注入工の使用材料を表-3 に示す。なお，採 取した表土は，レキなどが多く含まれおり，約 $30 \mathrm{~mm}$ およ び約 $20 \mathrm{~mm}$ のスクリーンで節にかけたものを配合した。

\section{3. 植生モニタリング}

\section{1 調査時期および調査方法}

植生モニタリング方法を表-4 に示す。調查時期は, 第 1 回 調查 2012 年 8 月と第 2 回調查 2013 年 8 月の 2 回である。 調查項目は, 斜面全体の植被率, 出現種および見取り調查で ある。それぞれの調査方法は表-4 に示した。

\section{2 調査結果および考察}

\subsection{1 斜面全体の植被率}

斜面全体の植被率の経過を図- 1 に示す。第 2 回調查の 2013 年 8 月調查時の斜面全体の植被率は, 2011 年 1 月施工区 (施 工後 2 年 7 力月経過） が $70 \%, 2012$ 年 2 月施工区（施工後 1 年 6 力月経過）が $40 \%$ であった。緑化速度は緩慢ではある が増加傾向にある。前述したとおり斜面の勾配は均一では無 く, 急勾配部では植被率が低く, 緩勾配では植被率が高く, 全体的にモザイク状に植生が分布していた（写真-3）。また, 法枠工内の枠内の下部に植物が多く成立している傾向が見ら れる。これは, 法枠内下部の水分条件が良好であることが原 因と考えられる。

\section{2 .2 出現種}

第 1 回および第 2 回調查で確認した出現種の一覧を表 -5 に 示寸。 2011 年 1 月施工区の出現種は, 2012 年 8 月調查では 在来草本 15 種, 外来草本 9 種の合計 24 種であった。 2013 年 8 月調查では在来草本 17 種, 外来草本 15 種の合計 32 種 に増加していた。特に外来草本の増加が著しい。

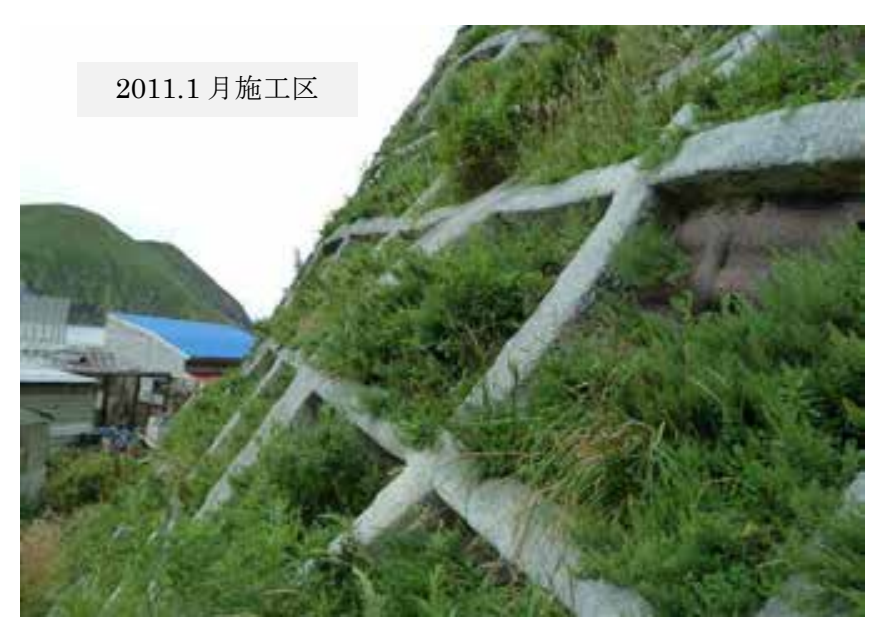

写真-3 第 2 回調査における斜面の近景 (2013 年 8 月 23 日撮影)
表-3 植生基材注入工の使用材料（100 $\mathrm{m}^{2}$ 当り）

\begin{tabular}{|c|c|c|c|}
\hline \multirow{2}{*}{ 材料区分 } & 植生基材注入工 & \multirow{2}{*}{ 単位 } & \multirow{2}{*}{ 数量 } \\
\hline & （商品名エコアップ緑化工法） & & \\
\hline \multirow{4}{*}{$\begin{array}{l}\text { 客土注入 } \\
\text { マット }\end{array}$} & 注入用特殊織袋 & $\mathrm{m}^{2}$ & 135 \\
\hline & （ソウケンフォーム BF-100） & & \\
\hline & 主アンカーピン D10-300 mm & 本 & 236 \\
\hline & 補助アンカーピン D10-200 mm & 本 & 236 \\
\hline \multirow[t]{4}{*}{ 生育基盤材 } & 特殊生育基盤材（オーガニック用土） & 紧 & 7,300 \\
\hline & 特殊緑化基材（ソウケンオーガ II ） & $\mathrm{kg}$ & 146 \\
\hline & 現地採取表土（ふるい調整） & 紧。 & 1,460 \\
\hline & 特殊有機肥料（ソウケンオーガ I ） & $\mathrm{kg}$ & 73 \\
\hline
\end{tabular}

表-4 植生モニタリング方法

\begin{tabular}{lll}
\hline & 項目 & \multicolumn{1}{c}{ 内容 } \\
\hline 調 査 & 第 1 回調査 & 2012 年 8 月 3 日 \\
時期 & 第 2 回調査 & 2013 年 8 月 23 日 \\
\hline 調 查 & 斜面全体の & 斜面全体を見渡し, 目視により植物で覆われてい \\
項目 & 植被率 & る割合（枯葉等を含む）を測定した。 \\
& 出現種 & 調査対象斜面の法尻を踏査し, 確認できる出現種 \\
& & を記録した。 \\
& 見取り調査 & 生育基盤の侵食など異常があれば記録した。 \\
\hline
\end{tabular}

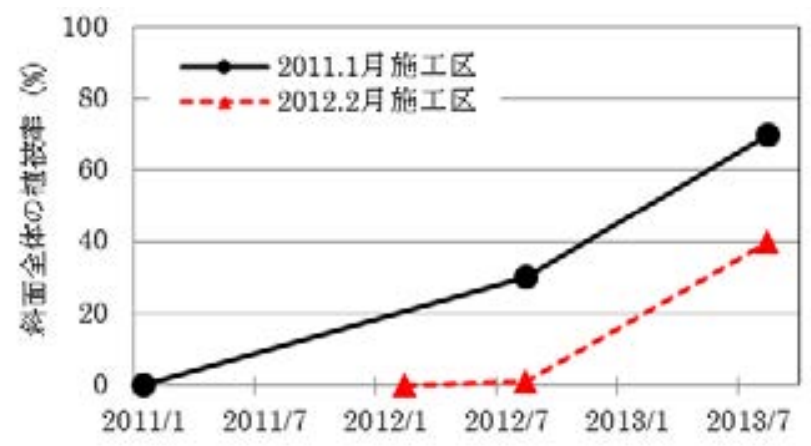

図-1 斜面全体の植被率の経過

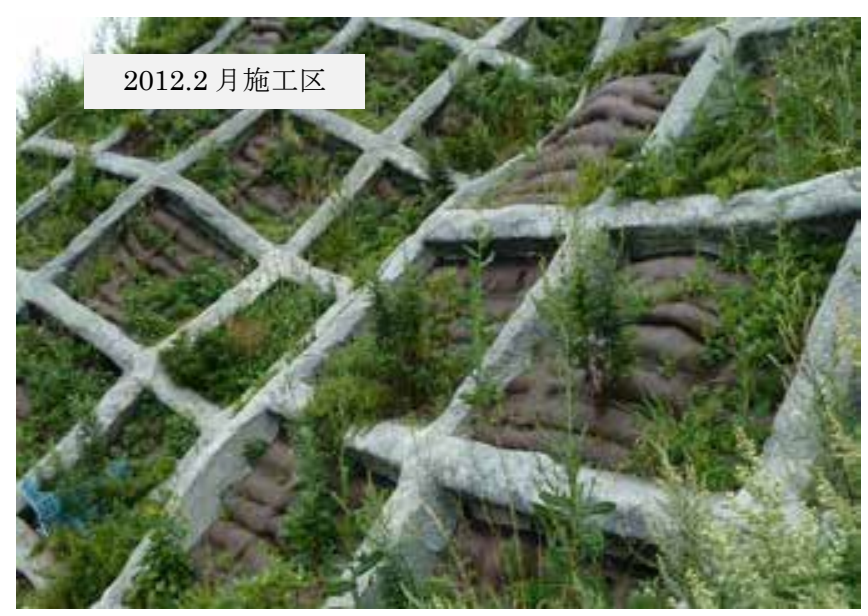


表-5 出現種一覧

\begin{tabular}{|c|c|c|c|c|c|c|}
\hline \multirow[b]{2}{*}{ 区分 } & \multirow[b]{2}{*}{ 植物名 } & \multirow[b]{2}{*}{ 科名 } & \multicolumn{2}{|c|}{ 2011.1月施工区 } & \multicolumn{2}{|c|}{2012.2 月施工区 } \\
\hline & & & $\begin{array}{c}2012.8 \text { 月 } \\
\text { 調查 }\end{array}$ & $\begin{array}{c}2013.8 \text { 月 } \\
\text { 調查 } \\
\end{array}$ & $\begin{array}{c}2012.8 \text { 月 } \\
\text { 調查 }\end{array}$ & $\begin{array}{c}2013.8 \text { 月 } \\
\text { 調查 } \\
\end{array}$ \\
\hline \multirow{26}{*}{ 在来草本 } & アカバナエソノノコギリソウ & キク科 & 0 & & & \\
\hline & アサギリソウ & キク科 & $\bigcirc$ & O & & O \\
\hline & イワヨモギ & キク科 & & O & & \\
\hline & エゾオオバコ & オオバコ科 & 0 & O & & 0 \\
\hline & エソオオグルマ & キク科 & $\bigcirc$ & O & O & \\
\hline & エゾノクサイチゴ & バラ科 & $\bigcirc$ & & & \\
\hline & オオイタドリ & タデ科 & $\bigcirc$ & 0 & & $\mathrm{O}$ \\
\hline & オオバコ & オオバコ科 & 0 & & & \\
\hline & オオョモギ & キク科 & $\bigcirc$ & 0 & 0 & 0 \\
\hline & オトコヨモギ & キク科 & & O & & O \\
\hline & カンチコウゾリナ & キク科 & & & & 0 \\
\hline & キジムシロ & バラ科 & & $\bigcirc$ & & \\
\hline & キタノコギリソウ & キク科 & & $\mathrm{O}$ & & \\
\hline & クサヨシ & イネ科 & $\bigcirc$ & 0 & O & $\mathrm{O}$ \\
\hline & ゴボウ & キク科 & 0 & & & \\
\hline & シカギク & キク科 & 0 & 0 & & 0 \\
\hline & スベリヒユ & ナデシコ科 & & & & 0 \\
\hline & ツリガネニンジン & キキョウ科 & & 0 & & 0 \\
\hline & ノゲシ & キク科 & $\bigcirc$ & 0 & & O \\
\hline & 八チジョウナ & キク科 & $\bigcirc$ & & & \\
\hline & ハマムギ & イネ科 & & 0 & & 0 \\
\hline & ハンゴンソウ & キク科 & & 0 & & \\
\hline & ヒロハクサフジ & マメ科 & 0 & O & & \\
\hline & $\exists モ キ ゙$ & キク科 & & & & 0 \\
\hline & レブンイワレンゲ & ベンケイソウ科 & 0 & 0 & 0 & \\
\hline & \multicolumn{2}{|c|}{$\begin{array}{l}\text { 在来草本出現種数 } \\
\end{array}$} & 15 & 17 & 4 & 13 \\
\hline \multirow{17}{*}{$\begin{array}{c}\text { 外来草本 } \\
\ldots\end{array}$} & アカザ & アカザ科 & & O & & $\mathrm{O}$ \\
\hline & エソノノギシギシ & タデ科 & & O & & 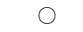 \\
\hline & オオアワガエリ (Tim) & イネ科 & & 0 & & \\
\hline & オニウシノケグサ $(\mathrm{TF})$ & イネ科 & $\bigcirc$ & O & & 0 \\
\hline & オニノゲシ & キク科 & $\bigcirc$ & 0 & & \\
\hline & カモガヤ (OG) & イネ科 & & O & & $\mathrm{O}$ \\
\hline & グンバイナズナ & アブラナ科 & $\bigcirc$ & O & & 0 \\
\hline & シロツメクサ（WC) & マメ科 & $\bigcirc$ & O & & \\
\hline & セイヨウアブラナ & アブラナ科 & $\bigcirc$ & $\mathrm{O}$ & & \\
\hline & ナガハグサ (KBG) & イネ科 & $\bigcirc$ & O & & \\
\hline & ハイウシノケグサ (CRF) & イネ科 & & O & & $\mathrm{O}$ \\
\hline & ヒメムカショモギ & キク科 & $\bigcirc$ & 0 & & 0 \\
\hline & ヘラオオバコ & オオバコ科 & $\bigcirc$ & O & & 0 \\
\hline & マルバトゲチシャ & キク科 & 0 & 0 & & O \\
\hline & ムラサキツメクサ & マメ科 & & 0 & & 0 \\
\hline & \multicolumn{2}{|c|}{ 外来草本出現種数 } & 9 & 15 & 0 & 10 \\
\hline & \multicolumn{2}{|c|}{ 出現種合計 } & 24 & 32 & 4 & 23 \\
\hline
\end{tabular}

※ 清水矩宏他著の日本帰化植物写真図鑑 ${ }^{3)}$ に掲載されている種を外来種とした。

2012 年 2 月施工区の出現種は, 2012 年 8 月調查では在来 草本 4 種, 外来草本 0 種の合計 4 種であった。この段階は植 被率 $5 \%$ 以下でほとんど裸地状態であった。2013 年 8 月調査 では在来草本 13 種, 外来草本 10 種の合計 23 種に増加して いた。2011 年 1 月施工区と同様に外来草本の増加が著しい。 優占種の測定は実施していないが，オオヨモギ（Artemisia montana (Nakai) Pamp.) ，オトコヨモギ（Artemisia japonica Thunb.)，ヒメムカショモギ (Erigeron canadensis L.）などが目立っていた。

撒きだし試験では多くの木本植物を確認していたが，2011 年 1 月施工区および 2012 年 2 月施工区ともに 2013 年 8 月 調査では木本植物を確認することが出来なかった。撒きだし 試験による出現種と実際の斜面における出現種は異なるとの 報告 ${ }^{4)}$ があるが，本事例においても同様な傾向が見られる。 なお，木本植物に関しては，播種後数年後に発芽することも 考えられることから今後の調査で注意深く観察する予定であ る。
また，多くの外来草本が確認された。外来草本の中には, オニウシノケグサ (Festuca arundinacea Schreb.) ，ナガ八 グサ (Poa pratensis L. subsp. pratensis) ， ハイウシノケグ サなど北海道の斜面緑化で利用される外来草本類が多く見ら れた。外来草本の種子は，採取した表土に含まれていた種子 と施工後に周辺から自然侵入した種子が考えられる。なお， 調查斜面の周辺には，過去に外来草本などで緑化を実施した と思われる斜面がある。表土利用工を実施する場合には，表 土に含まれている外来種だけでなく緑化対象斜面周辺からの 自然侵入にも留意する必要があることが示唆される。

\section{2 .3 見取り調查}

目視観察の結果，第 1 回および第 2 回調查ともに，斜面の 侵食は見られ無かった。客土注入マットからの生育基盤材の 流亡やマットの破れなど変状は見られ無かった（写真-3 参 照）。

\section{4. 今後の課題}

国立公園内など自然度が高い地域ほど表土の採取源が少な く，良質な表土を確保することが困難である。緑化対象斜面 全面に表土を配合するのでなく，部分的に表土を配合するな ど効率的な表土利用の検討が必要と考えられた。また，自生 種の種子を利用寸る地域性種苗利用工や種子を配合しない自 然侵入促進工などを組み合わせる方法も必要と思われる。

また，調查地で成立した外来種は，表土に含まれるものだ けでなく，法面周辺からの自然侵入が見られた。生物多様性 保全に配慮した緑化を実施する場合には，表土などの使用材 料だけでなく法面周辺に生育する外来種を確認することが重 要であることを再認識した。

これらの知見を積み重㸚, 生物多様性保全に配慮した緑化 技術の発展に寄与したいと考えている。

謝辞：本モニタリングを行うにあたり、フィールドをご提供 いただいた北海道宗谷総合振興局林務課に厚くお礼申し上げ ます。

\section{引用文献}

1）北海道地方環境事務所（2007）利尻礼文サロベツ国立公園 管理計画書, $81 \mathrm{pp}$.

2）国土交通省国土技術政策総合研究所（2013）地域生態系の 保全に配慮したのり面緑化工の手引き, 185 pp.

3）清水矩宏・森田弘彦・廣田伸七（2001）日本帰化植物図鑑, 全国農村教育協会, $554 \mathrm{pp}$.

4）上田徹・高政鉉・森本幸弘（2005）自然公園区域における 既存林修復の可能性実験（II），日本緑化工学会誌，31（1） : 103-106.

(2014. 5. 28 受理) 